\title{
Status of the Indus River dolphin Platanista minor
}

\author{
Randall R. Reeves and Abdul Aleem Chaudhry
}

The endemic freshwater dolphins in the Indus River system of Pakistan, Platanista minor, have been considered endangered since the early 1970 s. Measures taken to protect them from deliberate capture seem to have stopped a rapid decline, and combined counts in Sindh and Punjab provinces since the early 1980s suggest a total population of at least a few hundred animals. Severe problems remain, however. In addition to the risks inherent to any species with an effective population size in the low hundreds (at most), these dolphins are subject to long-term threats associated with living in an artificially controlled waterway used intensively by humans. Irrigation barrages partition the aggregate population into discrete subpopulations for much of the year. Dolphins that 'escape' during the flood season into irrigation canals or into reaches downstream of barrages where winter water levels are low have little chance of survival. A few dolphins probably die each year after being caught in fishing nets. Pollution by untreated urban sewage, agricultural runoff and industrial effluent threatens the health of the entire Indus system. The future of this dolphin species depends on Pakistan's commitment to protecting biological diversity in the face of escalating human demands on dwindling resources.

\section{Introduction}

The Indus River dolphin Platanista minor, known locally as bhulan, is endemic to the Indus River system of Pakistan. Human economic development of the Indus Basin has involved several major water impoundments in the upper reaches, primarily to generate electricity (Table 1, Figure 1). Numerous low gated dams, or barrages, have also been constructed in the middle and lower reaches of the Indus mainstem and its major tributaries, primarily to retain and divert water for irrigation and other human uses. These structures have partitioned the dolphin population into a number of subpopulations, some of which have been extirpated (Roberts, 1977; Khan and Niazi, 1989). The reduced water flow in downstream reaches, together with the construction of levees or 'bunds' to manage flooding in low-lying areas, has drastically reduced the amount of available habitat.
In the early 1970s, G. Pilleri and his coworkers called world attention to the fact that Indus dolphins were declining rapidly (Pilleri and Zbinden, 1973-74; Pilleri, 1980). With international support, the government of Sindh initiated a series of dolphin counts and officially declared the segment of the Indus mainstem between Sukkur and Guddu barrages a game reserve for dolphins (see Figure 1). In 1974, when the reserve was established, people were still practicing a tradition of hunting dolphins for meat and oil (Eates, 1968; Pilleri, 1972; Pilleri and Zbinden, 1973-74). These dolphin hunters were forced to move away from the reserve, and most of them had relocated upriver to Punjab by 1977 . The dolphin population in the Sukkur-Guddu segment apparently recovered to a considerable degree after 1974, with counts ranging to as high as 429 in 1986 (Khan and Niazi, 1989) compared with only 150 in 1974 (Pilleri and Zbinden, 1973-74). Initial reports from Punjab, 
by contrast, indicated that the number of dolphins there was still declining rapidly in 1986
(Khan and Niazi, 1989). These reports, however, may have been ill-founded. Counts

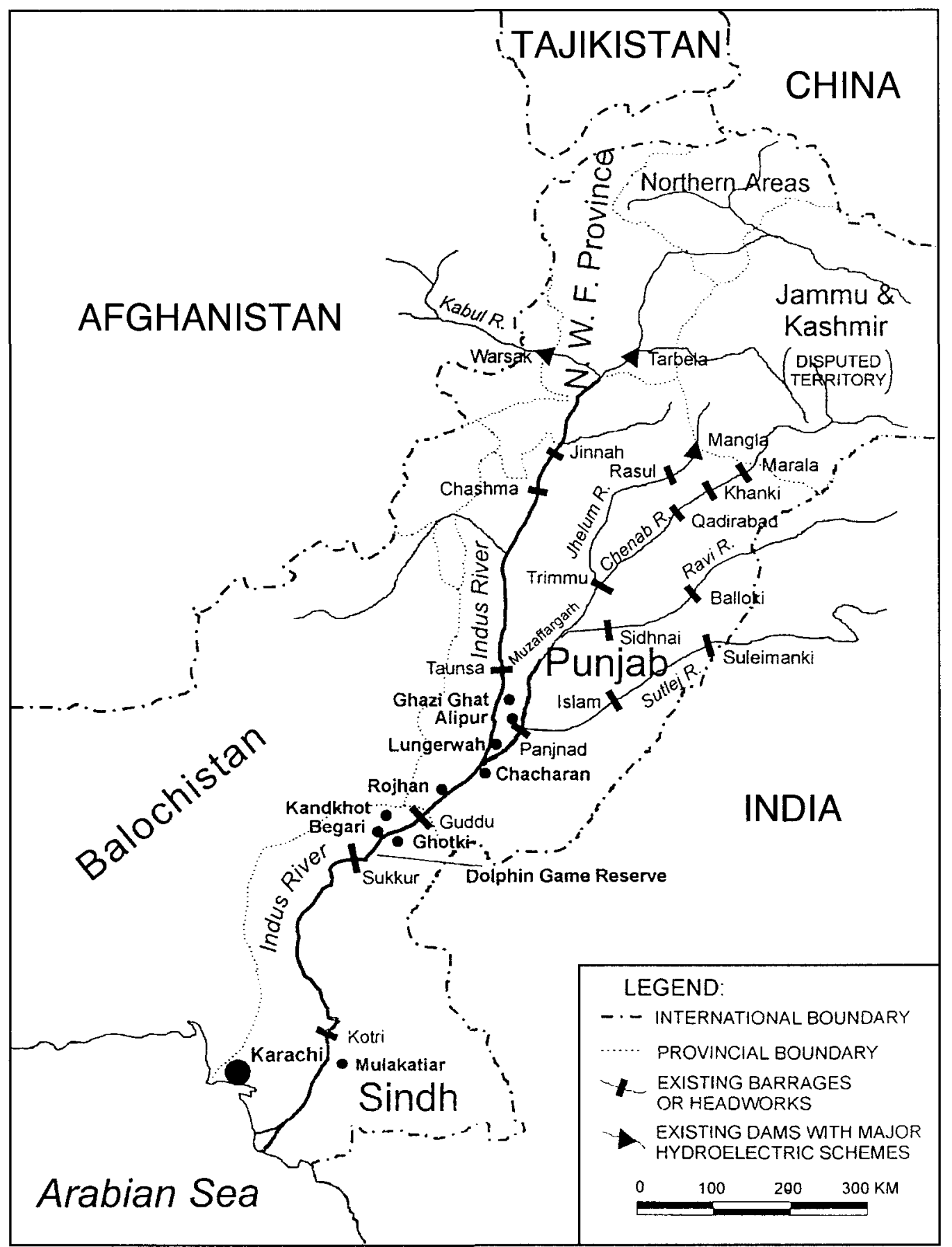

Figure 1. Indus River system showing locations of major dams and barrages (prepared by P. Barry). 


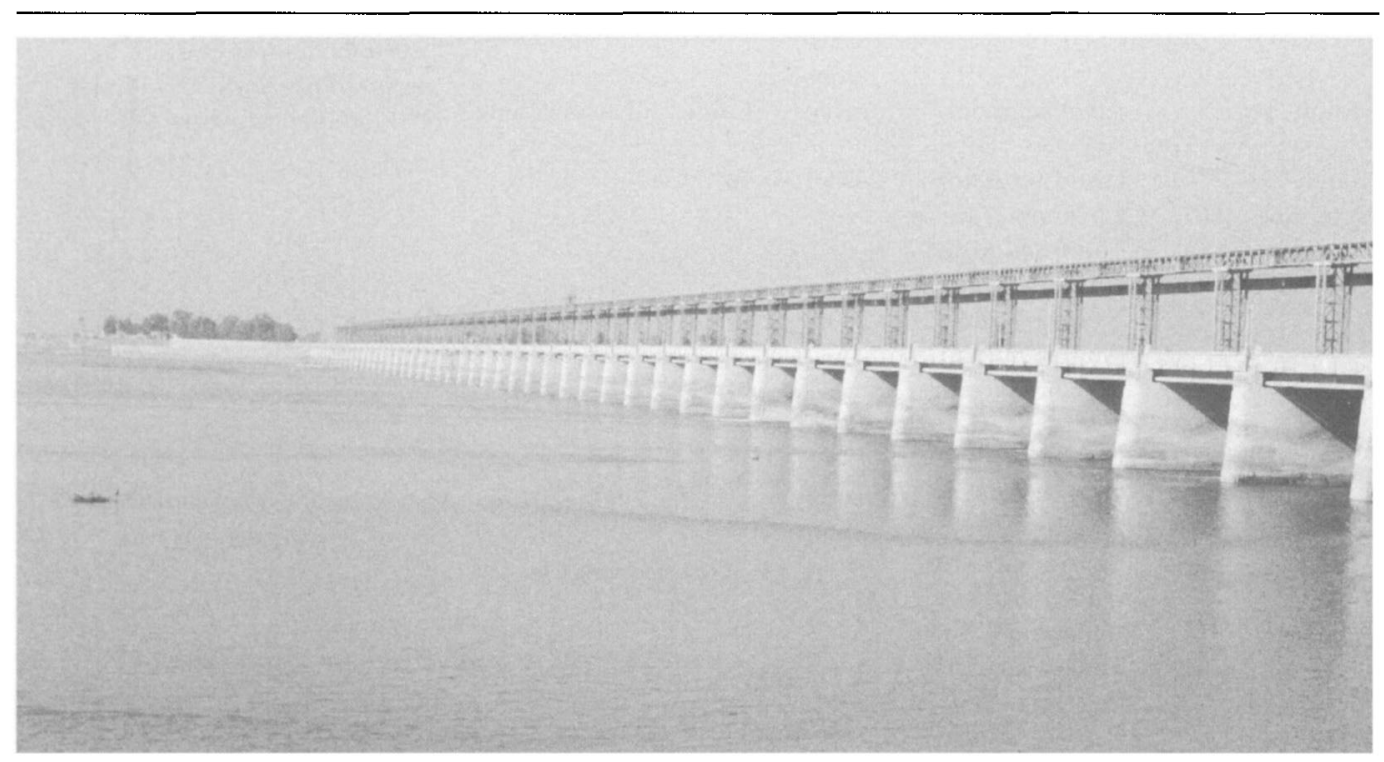

Above: Barrages, such as this one at Taunsa in Punjab, supply Pakistan's vast irrigation network by diverting water from the Indus River into man-made canals. Irrigated agriculture is vital to Pakistan's economy, yet large-scale water abstraction, regulation of flow and barrier effects of barrages profoundly affect biotic diversity in the Indus system (Randall Reeves).

Below: The long, forceps-like jaws of the platanistoid river dolphins distinguish them from all other small cetaceans. This skull is that of a large, old Indus dolphin found dead on the river bank just downstream of Guddu Barrage, Sindh, in early 1996 (Randall Reeves).

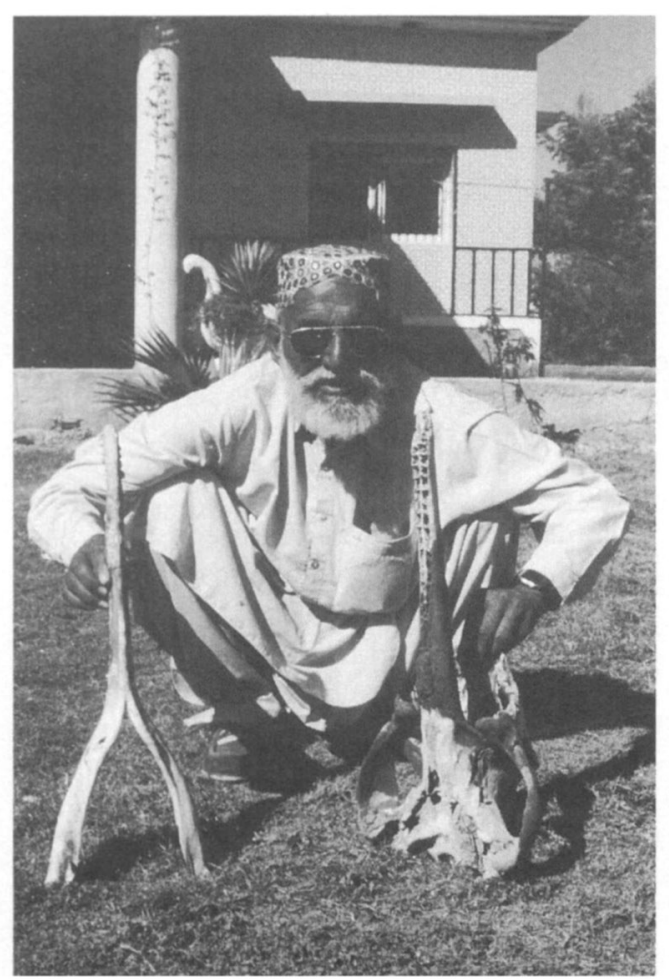

Table 1. Dams and barrages built in the Indus River system, with year of commissioning

\begin{tabular}{lll}
\hline & & \\
Name of facility & River & $\begin{array}{l}\text { Year of } \\
\text { commissioning }\end{array}$ \\
\cline { 2 - 3 } Kotri Barrage & Indus & 1954 \\
Sukkur Barrage & Indus & 1932 \\
Guddu Barrage & Indus & 1962 \\
Taunsa Barrage & Indus & 1959 \\
Chashma Barrage & Indus & 1971 \\
Jinnah Barrage & Indus & 1946 \\
Tarbela Dam & Indus & 1976 \\
Rasul Barrage & Jhelum & $1901 / 1967$ \\
Mangla Dam & Jhelum & 1967 \\
Panjnad Barrage & Chenab & 1932 \\
Trimmu Barrage & Chenab & 1939 \\
Qadirabad Barrage & Chenab & 1967 \\
Khanki Barrage & Chenab & 1891 \\
Marala Barrage & Chenab & $1912 / 1968$ \\
Sidhnai Barrage & Ravi & 1965 \\
Balloki Barrage & Ravi & $1913 / 1965$ \\
Islam Barrage & Sutlej & $1927 / 1965$ \\
Suleimanki Barrage & Sutlej & 1926 \\
Warsak Dam & Kabul & 1960 \\
\hline
\end{tabular}




\begin{tabular}{|c|c|c|c|c|}
\hline Month/year & River segment & $\begin{array}{l}\text { Non- } \\
\text { calves }\end{array}$ & Calves & Unspecified \\
\hline March 1987 & Guddu-Sukkur & 434 & 16 & - \\
\hline \multirow[t]{2}{*}{ November 1987} & Chashma-Taunsa & - & - & 47 \\
\hline & Taunsa-Guddu & - & - & 62 \\
\hline \multirow[t]{3}{*}{ March $1989^{*}$} & Chashma-Taunsa & 15 & - & - \\
\hline & Taunsa-Guddu & 80 & 3 & - \\
\hline & Guddu-Sukkur & - & - & 370 \\
\hline \multirow[t]{2}{*}{ April 1990} & Chashma-Taunsa & - & - & 20 \\
\hline & Taunsa-Guddu & - & - & 107 \\
\hline \multirow[t]{2}{*}{ November 1991} & Chashma-Taunsa & - & - & 35 \\
\hline & Taunsa-Guddu & - & - & 108 \\
\hline \multirow[t]{2}{*}{ November 1992} & Chashma-Taunsa & - & - & 49 \\
\hline & Taunsa-Guddu & - & - & 122 \\
\hline 1992 & Guddu-Sukkur & - & - & 439 \\
\hline \multirow[t]{2}{*}{ November 1993} & Chashma-Taunsa & - & - & 51 \\
\hline & Taunsa-Guddu & - & - & 111 \\
\hline \multirow[t]{2}{*}{ March 1994} & Chashma-Taunsa & 35 & 1 & - \\
\hline & Taunsa-Guddu & 112 & 12 & - \\
\hline \multirow[t]{2}{*}{ November 1994} & Chashma-Taunsa & - & - & 62 \\
\hline & Taunsa-Guddu & - & - & 100 \\
\hline \multirow[t]{2}{*}{ April 1995} & Chashma-Taunsa & 32 & 1 & - \\
\hline & Taunsa-Guddu & 119 & 3 & - \\
\hline \multirow[t]{2}{*}{ April 1996} & Chashma-Taunsa & - & - & 45 \\
\hline & Taunsa-Guddu & - & - & 122 \\
\hline \multirow[t]{2}{*}{ April/May 1996t } & $\begin{array}{l}\text { Guddu-Sukkur } \\
\text { (downstream) }\end{array}$ & 442 & 16 & - \\
\hline & $\begin{array}{l}\text { Sukkur-Guddu } \\
\text { (upstream) }\end{array}$ & 313 & 26 & - \\
\hline May/June 1996 & $\begin{array}{l}\text { Sukkur-Kotri } \\
\text { (both directions) }\end{array}$ & 0 & 0 & - \\
\hline May 1996 & $\begin{array}{l}\text { Kotri-Indus Delta } \\
\text { (both directions) }\end{array}$ & 0 & 0 & - \\
\hline \multirow[t]{2}{*}{ December 1996} & Chashma-Taunsa & - & - & 39 \\
\hline & Taunsa-Guddu & - & - & 143 \\
\hline
\end{tabular}

Table 2. Counts of dolphins reported by Sindh and Punjab Wildlife departments, 1987-1996

* Chaudhry and Khalid (1989).

t'At least three counts were made of each school and after deleting $10 \%$ of the count [to avoid double counting], the final count was recorded' (Mirza and Khurshid, 1996).

initiated by the Punjab Wildlife Department in 1987 indicate that more than 150 dolphins remain in the two segments of the Indus between Guddu and Chashma barrages (Chaudhry and Chaudhry, 1988; Chaudhry and Khalid, 1989; Reeves et al., 1991; Table 2).

The report by Khan and Niazi (1989), which emphasized the situation in Sindh, was considered current to 1986. Since that time, the wildlife departments in both Sindh and Punjab have attempted to monitor the dolphin populations in their respective jurisdictions, and international panels of experts have made several sets of recommendations for river dolphin research and conservation measures in Pakistan (Perrin and Brownell, 1989; Reeves et al., 1993; Reeves and Leatherwood, 1994, 1995). The main purpose of the present paper is to summarize and evaluate the results of dolphin surveys in the Indus since 1986 and to identify continuing threats to the species. We also suggest monitoring and management actions that might improve the Indus dolphin's long-term prospects for survival. 


\section{Survey methods and results}

The only detailed description of methods used to count dolphins in the Sukkur-Guddu segment is that attributed to K. M. Khan and M. S. Niazi in Perrin and Brownell (1989, pp. 17-18). Our own experience with surveys on the Indus makes us sceptical about certain aspects of the described methodology. For example, male and female dolphins cannot 'easily be recognized' from relative beak length as observed during surfacings. Nor can the two sexes be distinguished on the basis of 'sounds they produce in breathing'. Thus, we consider the male : female breakdown of the counts produced by Sindh researchers to be unreliable. The procedure of making two counts - 'one sailing downstream at full speed and the other upstream' - could not normally be followed using a 'locally made sailboat'. Even during the low water season, when the surveys are conducted (March-April or October-November), the current of the Indus mainstem is far too strong for sailing upstream in survey mode. Thus, we question the wisdom of using the mean of the two counts $\ldots$ as the estimate of the number of dolphins along the particular stretch of the river' (Perrin and Brownell, 1989, p. 18). Because the Sindh counts are always reported on the basis of 'school' size, it is impossible to judge whether animals are ever seen while traversing waters between the indicated localities of the 17 'schools' (e.g. Khan and Niazi, 1989, their Table 1; Mirza and Khurshid 1996).

In Punjab standard counts are made by Wildlife Department staff using a motorboat with two or three observers on board. The vessel travels downstream at slow speed (5-10 $\mathrm{km} / \mathrm{h}$ relative to the bank) without stopping. Surveys are timed to coincide with low water periods (October-November and MarchApril), when the main channel is generally 1-2 $\mathrm{km}$ wide. In reaches where the main channel is bifurcated or braided, the largest channel is surveyed first, followed by the secondary channel(s) as time and other logistical constraints permit. No attempt is made to classify the dolphins by sex or relative age, but youngof-the-year are noted as such. Positions of all sightings are recorded with respect to landmarks on shore (e.g., towns, bridges, ferry crossings and structures associated with barrages).

In view of the above reservations, the counts in Table 2 must be considered as no more than rough indices of abundance. According to the final report of the Sindh survey in 1996, 'double counts were avoided by deleting an average of $10 \%$ of the total population of the dolphin school' (Mirza and Khurshid, 1996). The Punjab counts are not adjusted to account for missed animals, and avoidance of double counting is left to the judgment of the chief of the survey team.

\section{Threats to the dolphin population}

\section{Population size and fragmentation}

The inherent risks associated with low population size (e.g. the stochastic effects of environmental flux, demographic structure, natural catastrophes and genetic problems) apply to Indus dolphins. Even if it is assumed that the reported counts are underestimates and that a few dolphins remain in unsurveyed areas upriver of Chashma and Panjnad barrages, the total population is probably fewer than 1000 individuals, making the effective population size well below 500 . A single dieoff comparable with those documented in recent years for several species of marine cetaceans (Geraci et al., in press) would have devastating consequences for the Indus dolphin.

Pilleri and Zbinden (1973-74) established the view that dolphins living between any two barrages are permanently isolated from other subpopulations (e.g. Kasuya and Nishiwaki, 1975). Reeves et al. (1991) suggested that movement downstream occurs during the flood season, when barrage gates are open, but that this movement represents a form of attrition for upstream (donor) subpopulations because there is virtually no movement from downstream to upstream of a barrage. People with first-hand experience at Sukkur and Taunsa barrages firmly believe, however, that some upstream movement past the barrages occurs (Hussain Bux Bhaagat, Abdul Munaf 
Table 3. Documented dolphin mortalities or reports of hunting and product use, post-1980

\begin{tabular}{|c|c|c|c|}
\hline Date & Locality & Details & Source \\
\hline 1983 & $\begin{array}{l}\text { Chashma B., } \\
\text { Taunsa B. and } \\
\text { near Ghazi Ghat }\end{array}$ & $\begin{array}{l}\text { Reports of captures for oil and to } \\
\text { eliminate competition. }\end{array}$ & $\begin{array}{l}\text { M.S. Niazi, pers. comm. } \\
\text { (see Reeves et al., 1991) }\end{array}$ \\
\hline 1989 & Taunsa B. & $\begin{array}{l}\text { Dolphin taken in fishing net; oil } \\
\text { saved. }\end{array}$ & Reeves et al. (1991) \\
\hline 1989 & Sukkur B. & $\begin{array}{l}\text { Carcass recovered from barrage } \\
\text { gate. }\end{array}$ & $\begin{array}{l}\text { K. M. Khan, pers. } \\
\text { comm. (see Reeves et al., 1991) }\end{array}$ \\
\hline $1989-90$ & Just below Jinnah B. & $\begin{array}{l}\text { Non-Muslim 'gypsies' reported to } \\
\text { hunt dolphins for meat. }\end{array}$ & $\begin{array}{l}\text { Newspaper article } \\
\text { (see Reeves et al., 1991) }\end{array}$ \\
\hline $1989-90$ & Guddu B. & Occasional capture in fishing nets. & $\begin{array}{l}\text { Bushra Parveen, pers. comm. } \\
\text { (see Reeves et al., 1991) }\end{array}$ \\
\hline Early 1990s & $\begin{array}{l}\text { Nara Canal, } 40-50 \\
\text { km from Sukkur }\end{array}$ & Two dolphins 'found' dead. & $\begin{array}{l}\text { Hussain Bux Bhaagat, } \\
\text { pers. comm. }\end{array}$ \\
\hline 1993 & Near Mulakatiar & $\begin{array}{l}\text { Dolphin killed, oil presented as a } \\
\text { gift to a village leader. }\end{array}$ & Mirza and Khurshid (1996) \\
\hline March 1994 & $\begin{array}{l}\text { Alipur, Lungerwah } \\
\text { and Bait Gul. Mohd } \\
\text { Shah areas }\end{array}$ & $\begin{array}{l}\text { Reports of dolphin hunting; sample } \\
\text { of oil obtained from fisherman at } \\
\text { Lungerwah (just upriver from } \\
\text { Khanwah). }\end{array}$ & PWD officer \\
\hline $\begin{array}{l}\text { November } \\
1994\end{array}$ & $\begin{array}{l}\text { Alipur, Muzaffar- } \\
\text { garh and Chacharan } \\
\text { areas }\end{array}$ & $\begin{array}{l}\text { Reports of catches in fish nets; } \\
\text { dolphins killed to reduce } \\
\text { competition and obtain oil. }\end{array}$ & PWD officer (Maqbool) \\
\hline April 1996 & $\begin{array}{l}\text { Alipur, Chacharam, } \\
\text { Rojhan areas }\end{array}$ & $\begin{array}{l}\text { Reports similar to those from } \\
\text { November } 1994 .\end{array}$ & PWD officer (Liaqat Ali) \\
\hline
\end{tabular}

PWD, Punjab Wildlife Department; SWD, Sindh Wildlife Department; B., Barrage.

Qaim Khani, Umeed Khalid, Sheh Zado Bahyo, pers. comm.). The barrage gates are open not only for 2-3 months during the flood season (June-September), but also for about 4 weeks in winter (December-January; low water season) while the canal regulators undergo routine maintenance. Thus, while we consider the subpopulations to be isolated for most of the year, we are uncertain about how much they might mix during these specific periods and about whether exchanges are in one (downstream) or both (downstream and upstream) directions.

\section{Deliberate and incidental captures}

The vulnerability of all cetacean species to capture in passive fishing gear, especially gillnets, is well established (Perrin et al., 1994). In the case of Indus dolphins, direct evidence of catching is scarce, but there is no doubt that it occurs (Roberts, 1977; Reeves et al., 1991).
Except at barrages little fishing takes place in the thalweg of the Indus. Commercial fishing rights for the areas immediately upstream of barrages (the 'head ponds' or reservoirs) are auctioned annually. Fishing is done mainly during the low-water season (October to February) with longlines and gill nets at night and with drag- (seine-), cast- and gill-nets as well as 'kurrlies' (one-person 'dip' nets) during the daytime (see Ahmad, 1966). Virtually all of the fishing is done using locally made, wooden, non-powered vessels. Although no regular effort is made in either Sindh or Punjab to document dolphin mortality, a few incidents have come to our attention (Table 3). The continuing local use of dolphin oil as liniment and livestock medicine, and the antipathy felt towards dolphins as competitors for fish and prawns, give fishermen some incentive to kill rather than release dolphins caught in their gear. Deliberate capture also apparently occurs on a small, localized scale. 
A 'kurrlie' seen immediately upstream of Taunsa Barrage, 1990. This is the same type of net that Pilleri and Zbinden (1973-74) claimed was used 'exclusively for catching dolphins' in the Sukkur-Guddu segment of the Indus during the early 1970 s (they called it 'kularee') (R. Reeves).

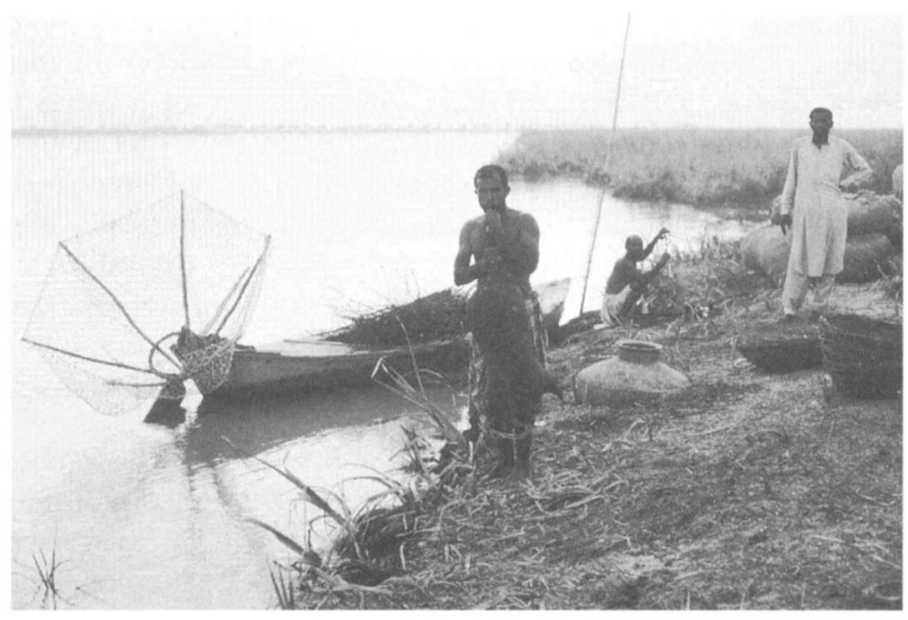

\section{Escapement into unsafe areas}

The natural flood cycle of any large river places animals at risk when they leave the main channel and disperse into seasonal streams and lakes during high-water periods. River dolphins are no exception. Some Gangetic dolphins Platanista gangetica apparently manage to survive from year to year in ox-bow lakes in Kaziranga National Park, Assam (Pilleri, 1970; T. J. Roberts in litt. to Reeves, 16 April 1990), but Indus dolphins that fail to return to the main channel and become trapped in floodplain lakes and streams, or in irrigation canals, have almost no chance of surviving. The same must be said of those that move downstream of Sukkur Barrage where the main channel narrows to only a few metres during winter and where fishing pressure is intensive (Mirza and Khurshid, 1996).

On two occasions, the Sindh Wildlife Department has managed to rescue and translocate dolphins from unsafe areas back into the reserve. In about 1992, a dolphin found in Rice Canal near Sukkur was netted, transported by boat back to the river and released (Hussain Bux Bhaagat, pers. comm.). In 1994, four or five dolphins that had become trapped in shallow pools downstream of Sukkur Barrage were caught and airlifted by helicopter to a holding pond near Sukkur. After a period of observation, they were released into the Indus above Sukkur Barrage (Abrar Hussain Mirza, pers. comm.). No systematic effort is made to locate 'escaped' dolphins, so rescue attempts such as these have been entirely ad hoc - the result of opportunistic notifications and personal initiatives.

\section{Pollution and other habitat degradation}

'Occurrence of massive fish kills and the destruction of lower aquatic forms due to indiscriminate use of pesticides in the agricultural fields along river banks and release of industrial pollutants into water bodies has become a common feature in various parts of the country' (Government of Pakistan, 1989, p.3). Tariq et al. (1996, p. 1343) recently described the Indus as 'a dump house for all types of waste products streaming into it via its tributaries'. Having assayed heavy metal and macronutrient contents of fish, sediment and water at Sukkur, Taunsa, Chashma and Jinnah barrages, these authors likened the pollution status of the Indus to those of the Thames, Rhine and Amazon. Preliminary analyses of water samples in the Indus mainstem between Chashma Barrage and the Chenab confluence have resulted in alarmingly high values of total dissolved solids (to $1768 \mathrm{mg} / \mathrm{L}$ at Taunsa in February-March, the low-water season) and chemical oxygen demand (to $10.8 \mathrm{mg} / \mathrm{L}$ at Chachran in August, the high-water season) 
(A. A. C., unpubl. data). Organic pollutants enter the river in the untreated sludge from urban centres and in the runoff from farm fields in rural areas. Industrial plants in Pakistan operate with few effective controls on effluent discharges. Tanneries and other factories discharge their chemical wastes, regardless of toxicity, into municipal sewers or, in some cases, directly into rivers (Chaudhry, 1994).

A large gas field, the Qadir Pur Field, is being developed along a $20-\mathrm{km}$ portion of the Indus, approximately in the centre of the dolphin reserve near Ghotki (Figure 1). In Phase I, completed in late 1995, eight wells went into production. Eight more are scheduled for Phase II, now under way. Although the wells situated in the floodplain are protected by wellhead islands built above the flood level, it was also judged necessary to build a $26-\mathrm{km}$ 'bund' (levee) to deflect flood waters and protect the production facilities. This levee, which was due to be completed before the 1997 flood season, would close a natural left-bank channel of the Indus. The geographic extent of the gas development project is bound to expand in the coming decades and will eventually include the even larger Kandkhot field on the right bank. No rigorous assessment of the potential impacts on dolphins has been done.

\section{Recommendations for monitoring and management}

\section{Dolphin surveys}

Regular surveys, whatever their methodological shortcomings, are important. They provide opportunities for wildlife department staff to detect major changes in the dolphin population's composition, distribution and abundance and in the condition of its habitat. Better co-ordination and co-operation should be sought between the Sindh and Punjab wildlife departments so that conservation strategies can be pursued at the metapopulation level rather than on the present piecemeal basis.

Count reporting should always include a detailed description of methods, effort and survey conditions. The male-female breakdown of the counts in Sindh puts an unrealistic onus on the field team and the report writer. It should be abandoned. Moreover, individual sightings should be reported, with number of animals and position given. Although the current procedure (in Sindh) of lumping counts into 'schools' may seem readily comprehensible to managers and the public, it reduces the analytical value of the data.

The procedure developed by Smith et al. (1994) of recording best, high and low counts at each river dolphin sighting should be adopted in both Sindh and Punjab. It provides an initial, albeit crude, means of accounting for uncertainty. Counts should routinely incorporate an effort to distinguish young-ofthe-year calves despite the difficulty of establishing objective criteria for identifying them. At a minimum, calf counts can provide a rough way of determining whether reproduction and recruitment are occurring in a given subpopulation.

\section{Rescue of escapees}

Systematic efforts should be made to detect, capture and translocate dolphins that enter canals or 'escape' into areas where they are at increased risk. A pilot study is needed to develop and evaluate rescue mechanisms. International support, both financial and technical, will be needed to set up rescue programmes, but the end goal should be to make them a normal part of the operations of the Sindh and Punjab wildlife departments.

\section{Patrolling and law enforcement}

Of all the threats to the species, the most clearcut and certain is deliberate killing. Major progress towards preventing dolphin killing has been made in both Sindh and Punjab over the past 25 years. The fact remains, however, that patrolling and enforcement are at best sporadic and at worst non-existent in many of the areas used by river dolphins. Wildlife protection agencies in Pakistan are chronically underequipped and underfunded. Morale is 
very low, particularly at the Sindh Wildlife Department office in Sukkur where the staff is idle much of the time. No powered vessel is available, and game officers must rely on their own initiative to travel along the river. Documentation of dolphin catches, whether accidental or deliberate, is essentially opportunistic. In addition to improved enforcement, there is a need for culturally appropriate public education efforts. Even though most people in Pakistan respect the Islamic injunction against consuming dolphin meat, they have no religious or economic motivation for protecting the animals.

\section{Water-use planning}

At least 67 per cent (World Bank, 1986) and possibly as much as 75 per cent (Anon, 1994) of the total outflow of the Indus is diverted into canals. The relentless increase in demand for fresh water for agricultural, industrial and household use ensures that this proportion will continue increasing towards 100 per cent. Quite apart from the implications for the Indus delta, with its formerly diverse and productive mangrove system, such drastic change to the freshwater budget has transformed the ecology of the entire Indus River system. While the economic losses caused by this transformation have been widely publicized and lamented, the losses of species diversity and abundance have been poorly documented and generally ignored (Carwardine, 1986; Government of Pakistan, 1989). Unless the importance of maintaining biological diversity is made integral to water-use planning in Pakistan, the river dolphin and many other species will, in the long term, simply run out of habitat.

\section{Environmental restoration}

The impetus for restoring water quality must come, in the first instance, from concern about human health. Authorities in Pakistan are well aware of the deteriorating quality of their water (Government of Pakistan, 1989), yet pollutant discharge rates continue to keep ahead of treatment efforts (cf. Chaudhry, no date,
1994). This situation is unlikely to change in the near future without massive, and costly, infrastructure development.

\section{Acknowledgements}

Support from the Sindh and Punjab Wildlife departments has made it possible for us to carry out our work in the Indus River system. Specific thanks are due to the Ocean Park Conservation Foundation (Hong Kong) and the Whale and Dolphin Conservation Society (Bath, UK) for sponsoring Reeves's recent visit to Pakistan and much of his other work on Asian river dolphins. Stephen Leatherwood played a key role in promoting and obtaining support for this study. Brian Smith and Tom Roberts shared useful data and references, and the comments of Tony Martin and an anonymous referee were most helpful.

\section{References}

Ahmad, N. 1966. West Pakistan Fisheries Manual. Government Printing Office, Lahore.

Anonymous. 1994. Indus: the life-line of Pakistan. Natura (WWF-Pakistan, Lahore), Spring-Summer, 9-11.

Carwardine, M. 1986. The Nature of Pakistan: A Guide to Conservation and Development Issues, 1. Conservation for Development Centre, IUCN, Gland, Switzerland; WWF-Pakistan, Lahore.

Chaudhry, A.A. No date. Biodiversity in the river Ravi. Natura (WWF-Pakistan, Lahore), 21 (3), 6-9.

Chaudhry, A.A. 1994. Conservation of the Indus dolphin: environmental pollution perspectives. Natura (WWF-Pakistan, Lahore), Spring-Summer, 2-4.

Chaudhry, A.A. and Chaudhry, S.A. 1988. Indus dolphin population on the increase in Punjab. Proceedings of the Pakistan Congress of Zoologists, 8, 209-214.

Chaudhry, A.A. and Khalid, U. 1989. Indus dolphin population in the Punjab. Proceedings of the Pakistan Congress of Zoologists, 9, 291-296.

Eates, K.R. 1968. Mammalia (Animals). In The Former Province of Sind (including Khairpur State). (ed. H. T. Sorley), pp. 35-52. Gazetteer of West Pakistan, Government of West Pakistan.

Geraci, J.R., Harwood, J. and Lounsbury, V. In press. Marine mammal die-offs. In Marine Mammals, Vol. 2 (eds J. R. Twiss and R. R. Reeves). Smithsonian Institution Press, Washington, D.C.

Government of Pakistan. 1989. Environmental Profile of Pakistan. Environment and Urban Affairs Division, Islamabad. 
Kasuya, T. and Nishiwaki, M. 1975. Recent status of the population of Indus dolphin. Scientific Reports of the Whales Research Institute (Tokyo), 27, 81-94.

Khan, K.M. and Niazi, M.S. 1989. Distribution and population status of the Indus dolphin, Platanista minor. In Biology and Conservation of the River Dolphins (eds W. F. Perrin, R. L. Brownell, Jr., K. Zhou and J. Liu), pp. 77-80. IUCN/SSC Occasional Paper 3, Gland, Switzerland.

Mirza, A.H. and Khurshid, S.N. 1996. Survey of the Indus dolphin Platanista minor in Sindh. World Wide Fund for Nature-Pakistan and Sindh Wildlife Department, Karachi.

Perrin, W.F. and Brownell, R.L., Jr. (eds) 1989. Report of the workshop. In Biology and Conservation of the River Dolphins (eds W. F. Perrin, R. L. Brownell, Jr., K. Zhou and J. Liu), pp. 1-22. IUCN/SSC Occasional Paper 3, Gland, Switzerland.

Perrin, W.F., Donovan, G.P. and Barlow, J. (eds) 1994. Gillnets and cetaceans. Report of the International Whaling Commission (Special Issue 15), Cambridge, UK.

Pilleri, G. 1970. Observations on the behaviour of Platanista gangetica in the Indus and Brahmaputra rivers. Investigations on Cetacea, 2, 27-60.

Pilleri, G. 1972. Field observations carried out on the Indus dolphin Platanista indi in the winter of 1972. Investigations on Cetacea, 4, 23-29.

Pilleri, G. 1980. The Secrets of the Blind Dolphins. Sind Wildlife Management Board, Wildlife and Forest Department, Government of Sindh, Karachi, Pakistan.

Pilleri, G. and Zbinden, K. 1973-74. Size and ecology of the dolphin population (Platanista indi) between the Sukkur and Guddu barrages, Indus River. Invest. Cetacea, 5, 59-69.

Reeves, R.R., Chaudhry, A.A. and Khalid, U. 1991. Competing for water on the Indus plain: Is there a future for Pakistan's river dolphins? Environmental Conservation, 18, 341-350.
Reeves, R.R., Leatherwood, S. and Mohan, R.S. Lal (eds). 1993. A Future for Asian River Dolphins: Report from a Seminar on the Conservation of River Dolphins in the Indian Subcontinent. Whale and Dolphin Conservation Society, Bath, UK.

Reeves, R.R. and Leatherwood, S. (eds). 1994. Dolphins, Porpoises, and Whales: 1994-1998 Action Plan for the Conservation of Cetaceans. IUCN/SSC Cetacean Specialist Group. IUCN, Gland, Switzerland.

Reeves, R.R. and Leatherwood, S. (eds). 1995. Report of the First Meeting of the Asian River Dolphin Committee, Ocean Park, Hong Kong, 5-7 December 1994. Ocean Park Conservation Foundation, Hong Kong.

Roberts, T.J. 1977. The Mammals of Pakistan. Ernest Benn Ltd, London.

Smith, B.D., Sinha, R.K., Regmi, U. and Sapkota, K. 1994. Status of Ganges river dolphins (Platanista gangetica) in the Karnali, Mahakali, Narayani and Sapta Kosi rivers of Nepal and India in 1993. Marine Mammal Science, 10, 368-375.

Tariq, J., Ashraf, M., Jaffar, M. and Afzal, M. 1996. Pollution status of the Indus River, Pakistan, through heavy metal and macronutrient contents of fish, sediment and water. Water Research, 30, 1337-1344.

World Bank. 1986. Pakistan and the World Bank: Partners in Progress. World Bank, Washington, DC.

Randall R. Reeves, Okapi Wildlife Associates, 27 Chandler Lane, Hudson, Quebec JOP 1H0, Canada.

A. Aleem Chaudhry, Punjab Wildlife Research Centre, PO Box 1513, Nishatabad, Faisalabad, Pakistan.

Received 20 March 1997

Accepted 18 August 1997 